\title{
Antioxidant Effect of Taurine Against Lead-Induced Oxidative Stress
}

\author{
H. Gürer, ${ }^{1}$ H. Özgünes, ${ }^{1}$ E. Saygin, ${ }^{2}$ N. Ercal ${ }^{3}$ \\ 1 University of Hacettepe, Faculty of Pharmacy, Department of Toxicology, 06100 Ankara, Turkey \\ 2 Department of Chemistry, University of Missouri-Rolla, Rolla, Missouri 65409-0010, USA \\ 3 Department of Medicine, Washington University School of Medicine, Box 8046, Lipid Research, 660 S. Euclid Ave., \\ St. Louis, Missouri 63110, USA
}

Received: 30 January 2001/Accepted: 11 May 2001

\begin{abstract}
Oxidative stress is proposed as a molecular mechanism in lead toxicity, which suggests that antioxidants might play a role in the treatment of lead poisoning. The present study was designed to investigate whether taurine has a beneficial effect both on Chinese hamster ovary ( $\mathrm{CHO})$ cells and on Fisher 344 (F344) rats following lead exposure. Therefore, oxidative stress parameters (glutathione, malondialdehyde levels, catalase, and glucose-6-phosphate dehydrogenase [G6PD] activities) of lead-exposed CHO cells and F344 rats were determined following taurine treatment. Taurine was found to be effective in (1) increasing glutathione levels that had been diminished by lead; (2) reducing malondialdehyde levels, an end-product of lipid peroxidation; (3) decreasing catalase and erythrocyte G6PD activity, which had been increased by lead exposure; and (4) improving cell survival of $\mathrm{CHO}$ cells. However, taurine had no effect on blood and tissue lead levels when $1.1 \mathrm{~g} / \mathrm{kg} / \mathrm{day}$ taurine was administered to F344 rats for 7 days, following 5 weeks of lead exposure (2,000 ppm lead acetate). As a result, taurine seems to be capable of fortifying cells against lead-induced oxidative attack without decreasing lead levels. Therefore, administration of taurine, accompanied by a chelating agent, might increase its effectiveness in the treatment of lead poisoning.
\end{abstract}

Lead poisoning is a multifaceted problem. Disruption of a variety of biochemical processes, rather than a single mechanism, is responsible for the toxicity. Although chelating agents are currently available for the treatment of lead poisoning, they have been shown to have many side effects and to be incapable of alleviating some toxic effects of lead (Cory-Slechta et al. 1987; Mortensen and Walson 1993; Porru and Alessio 1996). Accumulated evidence of lead's capacity to induce oxidative stress suggests that antioxidants may have an important role in abating some hazards of lead. We hypothesize that usage of an antioxidant agent in the

Correspondence to: N. Ercal; email: nercal@umr.edu presence of a chelator will increase the efficacy of the lead poisoning treatment.

We have previously shown that $\mathrm{N}$-acetylcysteine and lipoic acid, two well-known antioxidants, are effective in rebalancing the oxidant/antioxidant ratio in lead-exposed Chinese hamster ovary (CHO) cells and Fisher 344 (F344) rats (Ercal et al. 1996; Gurer et al. 1998, 1999a). Taurine, a sulfur-containing $\beta$-amino acid (Figure 1) is found in millimolar concentrations, especially in tissues that are excitable, rich in membranes, and generate oxidants (Jacobsen and Smith 1968; Wright et al. 1986). The sulfonate group in taurine is a strong acid that makes it completely zwitterionic over the physiological $\mathrm{pH}$ range (Huxtable 1992). A number of functions have been shown for taurine, such as maintaining calcium homeostasis, osmoregulation, removal of hypochlorous acid, and stabilizing the membranes (Gaull et al. 1985; Wright et al. 1986; Huxtable 1992). Some of the recent data indicate that taurine can act as a direct antioxidant by scavenging reactive oxygen species (ROS) (Cozzi et al. 1995; Redmond et al. 1996) and/or as an indirect antioxidant by preventing changes in membrane permeability due to oxidant injury (Nakashima et al. 1982; Banks et al. 1992; Gordon et al. 1992). However, some contradictory data have also been reported (Aruoma et al. 1988; Shi et al. 1997).

In the present study, the main goal was to investigate the effects of taurine on lead-induced oxidative stress in in vivo and in vitro systems. $\mathrm{CHO}$ cells were used as the in vitro model, while brain, kidney, and liver from lead-exposed F344 rats were analyzed as the in vivo model. To achieve the above goals, measurements of malondialdehyde (MDA) levels, as an indicator of lipid peroxidation; glutathione (GSH) levels, representing the thiol status of the cells; catalase (CAT) activity, as an important component of antioxidant defense system of the cells; and glucose-6-phosphate dehydrogenase (G6PD) activity, as an important reducing equivalent provider for erythrocytes were made. The possible protective effect of taurine against the cytotoxic effect of lead was examined in $\mathrm{CHO}$ cells. Lead concentrations from tissue and blood samples of F344 rats were further analyzed to evaluate whether taurine lowers lead levels in blood and tissues. 
$\mathrm{SO}_{3}^{-}$

1

\section{$\mathrm{CH}_{2}$}

1

\section{$\mathrm{CH}_{2}$}

$\mathrm{NH}_{3}{ }^{+}$

Fig. 1. Chemical structure of taurine at $\mathrm{pH} 7.4$

\section{Materials and Methods}

\section{Materials}

The N-(1-pyrenyl)-maleimide, 1,1,3,3-tetramethoxypropane, and 2-vinyl pyridine were purchased from Aldrich (Milwaukee, WI). All other chemicals were purchased from Sigma (St. Louis, MO). HPLC-grade reagents were used in GSH and MDA analysis.

\section{Cell Culture Studies}

CHO cells were propagated in Ham's F12 culture media supplemented with $10 \%$ fetal calf serum and $0.5 \%$ glutamine. Cells were maintained at $37^{\circ} \mathrm{C}$ in a humidified atmosphere of $5 \% \mathrm{CO}_{2}$ and $95 \%$ air.

Colony Formation Assays: Exponentially growing cells were collected after trypsinization and centrifuged at $1,000 \mathrm{~g}$ for $5 \mathrm{~min}$. The resulting cell pellets were resuspended in fresh media and counted on a hemocytometer. Between 100-2,000 cells were plated into small (60-mm) petri dishes and incubated for $4 \mathrm{~h}$ to allow cell attachment. Cells were then exposed to gradually increasing concentrations of lead as lead acetate $(0$ to $500 \mu \mathrm{M})$ for an additional $6 \mathrm{~h}$. Following lead treatment cells were washed and covered with $5 \mathrm{ml}$ of fresh media either plain or containing $10 \mathrm{mM}$ taurine and incubated for 7-10 days. At the end of incubation period, resulting cell colonies were stained with methylene blue and counted. Results reported from colony formation assays represent at least five separate experiments performed in triplicates. The colony efficiency (CE) was calculated as:

$$
\mathrm{CE}=\frac{\text { Colonies counted }}{\text { Cells seeded }} \times 100
$$

A cell survival curve was constructed by plotting the surviving fraction (number of colonies counted, divided by the number of cells seeded, times the colony efficiency of the control) from the "lead only" and "lead + taurine" groups versus the lead concentration.

Oxidative Stress Studies: $\quad \mathrm{CHO}$ cells $\left(5 \times 10^{5}\right.$ cells/flask) were plated into flasks and incubated for $4 \mathrm{~h}$ to facilitate attachment. Three groups were prepared. The "control group" was incubated in the basic media for $24 \mathrm{~h}$. The "lead only" group was incubated in $500 \mu \mathrm{M}$ lead acetate containing media for $20 \mathrm{~h}$. At the end of this period, lead-containing media were discarded and cells were incubated for additional $4 \mathrm{~h}$ in plain media. Cells from the "lead + taurine" group were exposed to 10 $\mathrm{mM}$ taurine containing media for $4 \mathrm{~h}$ following exposure to lead for
$20 \mathrm{~h}$. All solutions were freshly prepared prior to use. At the end of the incubation period, cells were trypsinized, resuspended in fresh media, and homogenized, then analyzed for oxidative stress parameters.

\section{Animal Studies}

All experiments were performed with F344 male rats weighing 75-100 g. The animals were housed in stainless steel cages in a temperaturecontrolled room $\left(22^{\circ} \mathrm{C}\right)$ with a $12 \mathrm{~h}$ light:dark cycle. They were fed with standard rat chow (Purina rat chow). The animals were randomized into three groups. Group I $(\mathrm{n}=10)$ served as the control and was given only standard rat chow and water for 6 weeks. Group II $(n=10)$ received 2,000 ppm lead acetate in drinking water for 5 weeks and received plain water only during the 6 th week. Group III $(n=5)$ received 2,000 ppm lead acetate in drinking water for 5 weeks and, during the 6 th week, received $1.1 \mathrm{~g} / \mathrm{kg} / \mathrm{day}$ taurine in drinking water.

At the end of the 6th week, after overnight fasting, the animals were anesthetized with metofane, and blood samples were collected via intracardiac puncture using heparin as an anticoagulant. Plasma and the buffy coat were removed by centrifugation for $10 \mathrm{~min}$ at 3,000 $\mathrm{rpm}$. The red blood cells (RBCs) were washed three times with an equal volume of cold saline. The RBCs samples were maintained at $-70^{\circ} \mathrm{C}$ for MDA assays (not longer than 7 days) and at $4^{\circ} \mathrm{C}$ for CAT assay (not longer than 4 days) (Aebi 1984). The tissue samples were also collected after sacrificing and kept at $-70^{\circ} \mathrm{C}$ until analyzed.

GSH Determination: GSH levels were determined using the method developed by Winters et al. (1995). Briefly, tissue samples were homogenized in serine-borate buffer $(100 \mathrm{mM}$ Tris- $\mathrm{HCl}, 10 \mathrm{mM}$ boric acid, $5 \mathrm{mM}$ L-serine, $1 \mathrm{mM}$ DETAPAC, $\mathrm{pH}$ 7.4) and derivatized with $1.0 \mathrm{mM} \mathrm{N}$-(1-pyrenyl)maleimide (NPM) in acetonitrile. The samples were incubated for $5 \mathrm{~min}$, then acidified with 1:6 HCl: $\mathrm{H}_{2} \mathrm{O}$. The derivatized samples were filtered through a $0.2-\mu \mathrm{m}$ acrodisc and injected onto a $3-\mu \mathrm{m} \mathrm{C}_{18}$ column in a reverse-phase HPLC system. The GSH assays were performed with a Shimadzu HPLC system comprised of a model LC-10A pump, a model RF-535 spectrofluorometer ( $330 \mathrm{~nm}$ excitation, $380 \mathrm{~nm}$ emission), and a model SCL-10A system controller. The column (Astec, Whippany, NJ; $100 \times 4.6 \mathrm{~mm}$ ) was packed with $3-\mu \mathrm{m}$ pore size $\mathrm{C}_{18}$ packing material. Quantification of the peaks was performed with a Shimadzu model CR601 Chromatopac. The mobile phase consisted of $35 \%$ water, $65 \%$ acetonitrile, with $1 \mathrm{ml} / \mathrm{L}$ acetic acid and $1 \mathrm{ml} / \mathrm{L}$ phosphoric acid. The samples were eluted isocratically at a flow rate of $0.5 \mathrm{ml} / \mathrm{min}$. The results were given as $\mathrm{nmol} / \mathrm{mg}$ protein where protein concentrations were determined by using Bradford method (Bradford 1976).

MDA Determination: The samples were analyzed according to the Draper method (Draper et al. 1993) with the following modifications: Tissue samples were homogenized in serine-borate buffer; $0.250 \mathrm{ml}$ of homogenate was added to $0.650 \mathrm{ml}$ of $5 \%$ trichloroacetic acid and $0.100 \mathrm{ml}$ of $500 \mathrm{ppm}$ butylated hydroxytoluene in methanol. The sample was heated in a boiling water bath for $30 \mathrm{~min}$, followed by cooling on ice and centrifugation. The supernatant was reacted 1:1 $(\mathrm{v} / \mathrm{v})$ with saturated 2-thiobarbituric acid. The sample was again heated for $30 \mathrm{~min}$ followed by a second cooling on ice. One-half milliliter of the sample was extracted with $1.0 \mathrm{ml} \mathrm{n}$-butanol and centrifuged to facilitate phase separation. The supernatant was then filtered through a $0.45-\mu \mathrm{m}$ acrodisc and injected onto a reverse-phase $3-\mu \mathrm{m} \mathrm{C}_{18}$ column, $250 \times 4.6 \mathrm{~mm}$. The mobile phase used was $30 \%$ acetonitrile, $69.4 \%$ phosphate buffer $(5 \mathrm{mM}, \mathrm{pH}=7.0)$, and $0.6 \%$ tetrahydrofuran. The reaction mixture was eluted from the column isocratically at a flow rate of $0.75 \mathrm{ml} / \mathrm{min}$.

CAT Activity Determination: The activity of tissue CAT was determined spectrophotometrically (Beers 1952), which measured the dis- 
appearance of $10 \mathrm{mM} \mathrm{H}_{2} \mathrm{O}_{2}$ at $240 \mathrm{~nm}$. The equation used to determine the reduction of $\mathrm{H}_{2} \mathrm{O}_{2}$ was:

$$
A_{60}=A_{0} e^{-k t}
$$

where $\mathrm{k}=$ the rate constant dependent on CAT activity.

G6PD Activity Determination: Determination of G6PD activity was performed by using a spectrophotometer, as detailed in Tietz (1986), where glucose-6-phospate and $\mathrm{NADP}^{+}$were used as substrates. The enzyme activity is determined by measurement of the rate of increase (at $340 \mathrm{~nm}$ ) in NADPH concentration.

Protein Level Determination: $\quad$ Protein levels were spectrophotometrically estimated by the method of Bradford (1976) using concentrated Coomassie Blue (Bio-Rad). Absorbance of samples was measured at $595 \mathrm{~nm}$.

Hemoglobin Measurement: Hemoglobin contents of the erythrocyte samples were measured spectrophotometrically, as detailed by Tietz (1986).

Tissue and Blood Lead Levels: Lead levels were assayed by atomic absorption spectroscopy (Varian SpectrAA) by the CDC-certified analytical laboratory at the Springfield-Greene County Department of Public Health, Springfield, MO.

\section{Statistical Analysis}

The nonparametric Mann-Whitney $U$ test was used to analyze the significance of the differences between control and experimental groups.

\section{Results}

\section{Cell Culture Studies}

Colony Formation: Figure 2 represents the survival curve, generated by plotting the survival fractions of cells treated with lead in the presence or absence of taurine against increasing concentrations of lead. Incubation of $\mathrm{CHO}$ cells with lead inhibited colony formation in a concentration-dependent manner. The inhibitory effect of $500 \mu \mathrm{M}$ lead acetate on survival fractions of $\mathrm{CHO}$ cells was negated by $10 \mathrm{mM}$ taurine administration.

GSH Levels: Lead exposure significantly diminished GSH levels of CHO cells. GSH content of lead-exposed cells was notably increased in the taurine-supplemented group (Table 1).

MDA Levels: MDA levels of cells from control and treated groups are shown in Table 1. MDA levels were raised twofold by lead exposure. Incubation with taurine in lead-treated groups significantly decreased MDA levels.

CAT Activity: Lead exposure induced a significant increase in CAT activity of CHO cells. Increased CAT activity in leadexposed cells was slightly decreased by further incubating the cells with taurine, although the results were not statistically significant (Table 1).

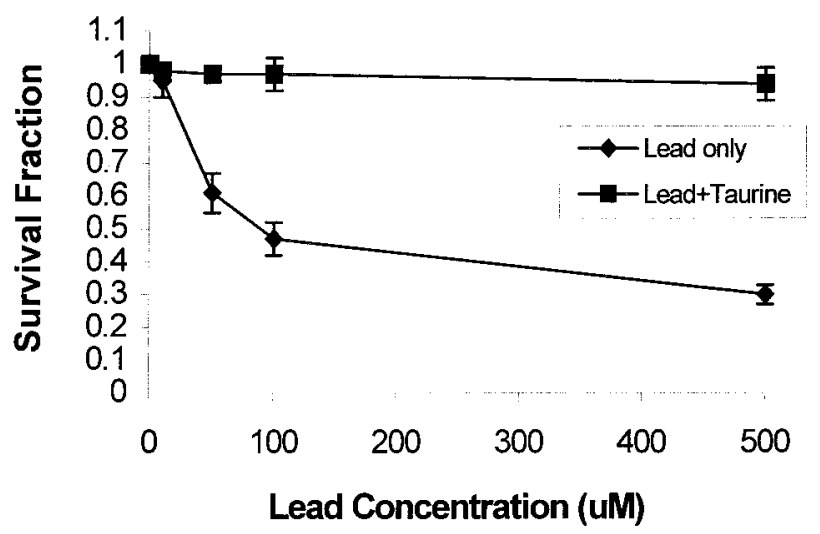

Fig. 2. Survival curve of $\mathrm{CHO}$ cells exposed to lead in the presence or absence of taurine

\section{Animal Studies}

GSH Levels: Lead exposure resulted in significantly reduced RBCs (Table 2) and brain (Table 3) GSH levels. Taurine administration, following lead exposure, was effective in increasing the diminished GSH levels both in RBCs and the brain (Tables 2 and 3). On the other hand, GSH levels increased in the kidneys of lead-exposed animals and were significantly higher in taurine-treated lead-exposed animals (Table 3).

MDA Levels: MDA levels were significantly elevated in RBCs (Table 2) brain and kidney (Table 3) of lead-exposed rats. Taurine administration markedly lowered MDA levels in all three tissues.

CAT Activity: Lead exposure caused an increase in CAT activity both in RBCs (Table 2) and kidney tissues (Table 3) of F344 rats. The enzyme activity reverted to control levels both in RBCs and kidney specimens of taurine-treated animals. Brain CAT activity was undetectable.

G6PD Activity: G6PD activity was measured in RBCs of the control, lead-exposed and taurine-treated F344 rats. Enzyme activity was considerably elevated following lead exposure. However, taurine treatment for 7 days significantly lowered the G6PD activity (Table 2).

Blood and Tissue Lead Levels: Table 4 shows the blood and tissue lead levels of control, lead-exposed and taurine-treated rats. Blood, brain and kidney lead levels were profoundly elevated after lead exposure. No significant effect of taurine on blood and tissue lead levels was observed following taurine administration.

\section{Discussion}

Our previous studies (Ercal et al. 1996; Gurer et al. 1998, 1999a) as well as the present one support the hypothesis indicated by several other groups (Ribarov and Bochev 1982; Ito et al. 1985; Monterio et al. 1985, 1991; Lawton and Donaldson 1991; Sandhir et al. 1994; Solliway et al. 1996) that 
Table 1. Selective oxidative stress parameters of lead-exposed $\mathrm{CHO}$ cells in the presence or absence of taurine

\begin{tabular}{lcll}
\hline & $\begin{array}{l}\text { GSH } \\
(\mathrm{nmol} / \mathrm{mg} \text { protein) }\end{array}$ & $\begin{array}{l}\text { MDA } \\
(\mathrm{nmol} / 100 \mathrm{mg} \text { protein) }\end{array}$ & $\begin{array}{l}\text { CAT } \\
(\mathrm{U} / \mathrm{mg} \text { protein) }\end{array}$ \\
\hline Control & $43 \pm 2.7$ & $22.7 \pm 2.7$ & $16.7 \pm 5.0$ \\
Lead only & $32 \pm 1.4^{*}$ & $45.5 \pm 6.0^{*}$ & $26.2 \pm 3.3^{\#}$ \\
Lead + taurine & $52.4 \pm 2.7^{* *}$ & $18.7 \pm 4.5^{* *}$ & $21.5 \pm 7.5$ \\
\hline
\end{tabular}

$* \mathrm{p}<0.01$, compared to the corresponding value of control group.

${ }^{\#} \mathrm{p}<0.05$, compared to the corresponding value of control group.

$* * \mathrm{p}<0.05$, compared to the corresponding value of lead group.

Table 2. Selective oxidative stress parameters of erythrocytes from lead-exposed F344 rats

\begin{tabular}{lllcl}
\hline & GSH $(\mathrm{nmol} / \mathrm{g} \mathrm{Hb})$ & MDA $(\mathrm{nmol} / \mathrm{g} \mathrm{Hb})$ & CAT $(\mathrm{U} / \mathrm{g} \mathrm{Hb})$ & G6PD $(\mathrm{U} / \mathrm{g} \mathrm{Hb})$ \\
\hline Control & $25 \pm 3$ & $40 \pm 7$ & $98 \pm 33$ & $22 \pm 1$ \\
Lead only & $17 \pm 2^{* *}$ & $62 \pm 20^{*}$ & $167 \pm 14^{* *}$ & $29 \pm 6^{*}$ \\
Lead + taurine & $21 \pm 1^{\S}$ & $36 \pm 7^{\S}$ & $93 \pm 23^{\S}$ & $24 \pm 1^{\S \S}$ \\
\hline
\end{tabular}

$* \mathrm{p}<0.005$, compared to the corresponding value of control group.

$* * \mathrm{p}<0.0005$, compared to the corresponding value of control group.

${ }^{\S} \mathrm{p}<0.005$, compared to the corresponding value of lead group.

$\S \S \mathrm{p}<0.05$, compared to the corresponding value of lead group.

Table 3. Oxidative stress related parameters from brains and kidneys of F344 rats

\begin{tabular}{|c|c|c|c|c|c|}
\hline & \multicolumn{2}{|l|}{ Brain } & \multicolumn{3}{|l|}{ Kidney } \\
\hline & $\begin{array}{l}\text { GSH } \\
\text { (nmol/mg protein) }\end{array}$ & $\begin{array}{l}\text { MDA } \\
\text { (nmol/100 mg protein) }\end{array}$ & $\begin{array}{l}\text { GSH } \\
\text { (nmol/mg protein) }\end{array}$ & $\begin{array}{l}\text { MDA } \\
\text { (nmol/100 mg protein) }\end{array}$ & $\begin{array}{l}\text { CAT } \\
\text { (U/mg prot.) }\end{array}$ \\
\hline Control & $18.4 \pm 1.4$ & $14.6 \pm 1.8$ & $0.07 \pm 0.04$ & $7.2 \pm 1.2$ & $0.15 \pm 0.03$ \\
\hline Lead only & $16.1 \pm 1.7^{*}$ & $21.4 \pm 0.7^{*}$ & $0.47 \pm 0.1^{*}$ & $10.3 \pm 0.3^{*}$ & $0.24 \pm 0.03^{*}$ \\
\hline Lead + taurine & $20.2 \pm 1.0 * *$ & $14.8 \pm 2.8^{* *}$ & $0.74 \pm 0.3 * *$ & $8.8 \pm 0.9 * *$ & $0.21 \pm 0.01 * * *$ \\
\hline
\end{tabular}

$* \mathrm{p}<0.005$, compared to the corresponding value of control group.

$* * p<0.01$, compared to the corresponding value of lead group.

$* * * \mathrm{p}<0.05$, compared to the corresponding value of lead group.

Table 4. Blood and tissue lead concentrations from F344 rats

\begin{tabular}{lllll}
\hline & $\begin{array}{l}\text { Blood Lead } \\
\text { Concentrations } \\
(\mu \mathrm{g} / \mathrm{dl})\end{array}$ & $\begin{array}{l}\text { Brain Lead } \\
\text { Concentrations } \\
(\mathrm{ppm})\end{array}$ & $\begin{array}{l}\text { Kidney Lead } \\
\text { Concentrations } \\
(\mathrm{ppm})\end{array}$ & $\begin{array}{l}\text { Liver Lead } \\
\text { Concentrations } \\
(\mathrm{ppm})\end{array}$ \\
\hline Control & $0.43 \pm 0.5$ & $0.08 \pm 0.1$ & $0.20 \pm 0.4$ & $0.08 \pm 0.08$ \\
Lead & $36.4 \pm 4.4^{*}$ & $1.30 \pm 0.6^{* *}$ & $10.8 \pm 1.6^{* *}$ & $1.3 \pm 0.6^{* *}$ \\
Lead + taurine & $33.8 \pm 2.0$ & $1.75 \pm 0.5$ & $13.3 \pm 1.7$ & $1.5 \pm 0.5$ \\
\hline
\end{tabular}

$* \mathrm{p}<0.0005$, compared to the corresponding value of control group.

$* * \mathrm{p}<0.005$, compared to the corresponding value of control group.

lead-induced oxidative stress could be, in part, responsible for lead-induced toxicity. In the present study, lead is shown to alter the oxidative stress-related parameters both in F344 rats in vivo and $\mathrm{CHO}$ cells in vitro. Decreased cell survival in leadexposed CHO cells was accompanied by increased lipid peroxidation and altered antioxidant defense systems, suggesting oxidative stress as a possible mechanism for lead-induced damage. Furthermore, in one of our earlier studies, treatment of lead-exposed $\mathrm{CHO}$ cells with superoxide dismutase + CAT was found to reverse MDA and GSH levels back to control levels indicating that part of this injury may be mediated by ROS (Gurer et al. 1999a). The possible curicial role of oxida- tive stress in the pathophysiology of lead toxicity brought up the idea that induced damage could be relieved in part by antioxidants. We previously suggested some thiol antioxidants such as N-acetylcysteine (NAC), lipoic acid, and captopril to restore the impaired prooxidant/antioxidant balance in lead toxicity (Ercal et al. 1996; Gurer et al. 1998, 1999a, 1999b). The antioxidant activity of succimer, a potent chelating agent with two free thiol groups, was also investigated in our lab (Ercal et al. 1996; Gurer et al. 1998). Both NAC and lipoic acid as known antioxidants and succimer as a chelator were found to bolster the cells against deleterious effects of lead. Captopril was also found to have beneficial effects to some extent. 
Although the mechanism of antioxidant activity in lead toxicity has not been fully elucidated yet, the free sulfhydryl group in their structure seems to play an alternate ROS scavenger role. On the other hand, taurine, a sulfur-containing $\beta$-amino acid, is also suggested as having a protective effect against oxidative damage induced by compounds such as carbon tetrachloride (Nakashima et al. 1982), bleomycin and paraquat (Gordon et al. 1992) and ethanol (Kerai et al. 1999). The following mechanisms have been proposed for the antioxidant effects of taurine: (1) As a direct antioxidant, taurine would quench and detoxify some reactive intermediates such as hypochlorous acid generated by myeloperoxidase (Wright et al. 1986; Huxtable 1992; Timbrell et al. 1995), nitric oxide (Redmond et al. 1996), and $\mathrm{H}_{2} \mathrm{O}_{2}$ (Cozzi et al. 1995). Taurine was also reported to have scavenged $\mathrm{HO}^{\circ}$, but this scavenging activity has been shown to be weak compared to that of glucose and mannitol (Aruoma et al. 1988). (2) As an indirect antioxidant, taurine may protect cells via intercalating into the membrane and stabilizing it (Nakashima et al. 1982; Gordon et al. 1992; Timbrell et al. 1995). The membrane-protective effect of taurine is suggested to be related to an action on permeability to ions and water (Wright et al. 1986; Timbrell et al. 1995).

In the light of this knowledge, the current study was undertaken to investigate whether taurine mitigates lead-induced oxidative damage in in vivo and in vitro models. The effects of taurine on MDA, as an endpoint indicator of lipid peroxidation, GSH, CAT, and G6PD activities as components of the antioxidant defense system were evaluated in lead-exposed $\mathrm{CHO}$ cells and F344 rats.

Lipid peroxidation, which was increased by lead exposure both in CHO cells and F344 rats, was found to be decreased following taurine supplementation. Lipid peroxidation is a chain reaction where ROSs are involved. Therefore, a molecule can inhibit the reactions by quenching ROSs. Although several studies (Cozzi et al. 1995; Redmond et al. 1996) reported that taurine scavenges ROSs, this finding has not been supported by several other groups (Aruoma et al. 1988; Shi et al. 1997). Taurine is known to be a powerful scavenger of hypochlorous acid ( $\mathrm{HOCl}$ (Thomas et al. 1986). The reaction of taurine with this oxidant yields a taurine chloramine, which is a known toxin for $\alpha_{1}$-antiproteinase; however $\mathrm{HOCl}$ does not seem to be involved in the lipid peroxidation process induced by lead. Therefore, the membrane-stabilizing effect of taurine and the resulting decline of membrane susceptibility to lipid peroxide formation seems more likely to happen. Furthermore, taurinesupplemented $\mathrm{CHO}$ cells demonstrated an increase in viability (as determined by the colony formation assay), along with a decrease in lipid peroxidation. This would also indicate that oxidative damage might contribute to the cell damage that occurred.

Further evidence of the efficacy of taurine in abating leadinduced oxidative stress includes the increase in GSH content and decreases in both CAT and G6PD activities in lead-treated cells or animals after taurine supplementation. Taurine does not have a known stimulating effect on GSH biosynthesis. On the other hand, GSH is known to react with and detoxify reactive species where its cellular levels are expected to decrease. The increases in MDA content in lead-exposed cells and tissues suggest that lead-stimulated lipid peroxidation results in the formation of aldehydic and reactive by-products, which, in turn, decrease GSH content. Therefore, it seems plausible that taurine can improve the antioxidant defense system via inhibiting the lipid peroxidation process, thereby mitigating the consumption of GSH. The same mechanism, rather than a direct effect on the enzymes, could also explain the beneficial effects of taurine on CAT and G6PD activities.

Taurine was shown to form less stable metal complexes with various transition metals, such as $\mathrm{Cu}^{2+}, \mathrm{Ni}^{2+}, \mathrm{Zn}^{2+}, \mathrm{Co}^{2+}$, $\mathrm{Cd}^{2+}, \mathrm{Fe}^{2+}, \mathrm{Mn}^{2+}, \mathrm{Mg}^{2+}$, than do other amino acids. Direct interaction between taurine and metal ions is mainly attributed to the electric association between metal cations and the sulfonate anion or to the interaction between metal ions and the nitrogen's unshared pair of electrons (Wright et al. 1986). The present study also explored whether taurine is capable of removing lead from some target tissues. Lead levels in blood, brain, kidney or liver specimens of rats from "lead" and "lead + taurine" groups were detected and compared. Taurine was shown to have no effect on tissue lead levels, indicating that its antioxidant effect shown in the present study is not a consequence of removal of lead from target tissues.

In conclusion, oxidative stress seems to contribute to leadinduced damage, even in animals with moderate blood lead levels $(36.4 \mu \mathrm{g} / \mathrm{dl})$. Therefore, including an antioxidant in the treatment protocol might increase the effectiveness of the treatment of lead poisoning. Taurine, as an amino acid with no known toxic effects to humans, seems to have a promising antioxidant effect against oxidative damage induced by lead. Although the present data is not designed to designate a singular molecular mechanism for the antioxidant effect of taurine, it seems likely that taurine would increase the efficacy of the treatment when administered together with a chelator. Otherwise, it would partially abate the toxic effects of lead in patients with low blood lead levels $(<45 \mu \mathrm{g} / \mathrm{dl})$ who are presently left untreated.

\section{References}

Aebi H (1984) Catalase in vitro. In: Packer L (ed) Methods of enzymology, vol. 105. Academic Press, New York, pp 121-126

Aruoma OI, Halliwell B, Hoey BM, Butler J (1988) The antioxidant action of taurine, hypotaurine and their metabolic precursors. Biochem J 256:251-255

Banks MA, Porter DW, Martin WG, Castranova V (1992) Taurine protects against oxidant injury to rat alveolar pneumocytes. In: Lombardini JB, Schaffer SW, Azuma J (eds) Taurine: nutritional value and mechanisms of action. Plenum Press, New York, pp $341-354$

Beers RF, Sizer IW (1952) A spectrophotometric method for measuring the breakdown of hydrogen peroxide by catalase. J Biol Chem 195:133-140

Bradford MA (1976) Rapid and sensitive method for the quantitation of microgram quantities of protein utilizing the principle of protein-dye binding. Anal Biochem 72:248-256

Cory-Slechta DA, Weiss B, Cox C (1987) Mobilization and redistribution of lead over the course of calcium disodium ethylenediamine tetraacetate chelation therapy. J Pharmacol Exper Therap 243:804-813

Cozzi R, Ricordy R, Bartolini F, et al. (1995) Taurine and ellagic acid: two differently-acting natural antioxidants. Environ. Mol Mutagen 26:248-254

Draper HH, Squires EJ, Mahmoodi H, Wu J, Agarwal S, Hadley MA (1993) Comparative evaluation of thiobarbituric acid methods for 
the determination of malondialdehyde in biological materials. Free Radic Biol Med 15:353-363

Ercal N, Treeratphan P, Hammond TC, Matthews, RH, Granneman $\mathrm{NH}$, Spitz DR (1996) In vivo indices of oxidative stress in leadexposed C57BL/6 mice are reduced by treatment with meso-2,3dimercaptosuccinic acid or N-acetylcysteine. Free Rad Biol Med 21:157-161

Gaull GE, Pasantes-Morales H, Wright CE (1985) Taurine in human nutrition: overview. In: Oja SS, Ahtee L, Kontro P, Paasonen MK (eds) Taurine: biological actions and clinical perspectives. Alan R. Liss, pp 3-21

Gordon RE, Heller RF, Heller RF (1992) Taurine protection of lungs in hamster models of oxidant injury: a morphologic time study of paraquat and bleomycin treatment. In: Lombardini JB, Schaffer SW, Azuma J (eds) Taurine: nutritional value and mechanisms of action. Plenum Press, New York, pp 319-323

Gurer H, Ozgunes H, Neal R, Spitz DR, Ercal N (1998) Antioxidant effects of $\mathrm{N}$-acetylcysteine and succimer in red blood cells from lead-exposed rats. Toxicol 128:181-189

Gurer H, Ozgunes H, Oztezcan S, Ercal N (1999a) Antioxidant role of alpha-lipoic acid in lead toxicity. Free Rad Biol Med 27:75-81

Gurer H, Neal R, Yang P, Oztezcan S, Ercal N (1999b) Captopril as an antioxidant in lead-exposed Fischer 344 rats. Hum Exp Toxicol 18:27-32

Huxtable RJ (1992) Physiological actions of taurine. Physiol Rev 72:101-144

Ito Y, Niiya Y, Kurita H, Shima S, Sarai S (1985) Serum lipid peroxide level and blood superoxide dismutase activity in workers with occupational exposure to lead. Int Arch Occup Environ Health 56:119-127

Jacobsen JG, Smith LN (1968) Biochemistry and physiology of taurine and taurine derivatives. Physiol Rev 48:424-511

Kerai MDJ, Waterfield CJ, Kenyon SH, Asker DS, Timbrell JA (1999) Reversal of ethanol-induced hepatic steatosis and lipid peroxidation by taurine: a study in rats. Alcohol Alcoholism 34:529-541

Lawton LJ, Donaldson WE (1991) Lead-induced tissue fatty acid alterations and lipid peroxidation. Biol Trace Elem Res 28:83-97

Monterio HP, Abdalla DSP, Arcuri AS, Bechara EJH (1985) Oxygen toxicity related to exposure to lead. Clin Chem 31:1673-1676
Monterio HP, Bechara EJH, Abdalla DSP (1991) Free radicals involvement in neurological porphyrias and lead poisoning. Mol Cell Biochem 103:73-83

Mortensen ME, Walson PD (1993) Chelation therapy for childhood lead poisoning. Clin Pediatr 32:284-291

Nakashima T, Taniko T, Kuriyama K (1982) Therapeutic effect of taurine administration on carbon tetrachloride-induced hepatic injury. Japan J Pharmacol 32:583-589

Porru S, Alessio L (1996) The use of chelating agents in occupational lead poisoning. Occup Med 46:41-48

Redmond HP, Wang JH, Bouchier-Hayes D (1996) Taurine attenuates nitric oxide- and reactive oxygen intermediate-dependent hepatocyte injury. Arch Surg 131:1287-1288

Ribarov SR, Bochev PG (1982) Lead-hemoglobin interaction as a possible source of reactive oxygen species - a chemiluminescent study. Arch Biochem Biophys 213:288-292

Sandhir R, Julka D, Gill KD (1994) Lipoperoxidative damage on lead exposure in rat brain and its implications on membrane bound enzymes. Pharmacol Toxicol 74:66-71

Shi X, Flynn DC, Porter DW, Leonard SS, Valllyathan V, Castranova V (1997) Efficacy of taurine based compounds as hydroxyl radical scavengers in silica induced peroxidation. Ann Clin Lab Sci $27: 365-374$

Solliway BM, Schaffer A, Pratt H, Yannai S (1996) Effects of exposure to lead on selected biochemical and hematological variables. Pharmacol Toxicol 78:18-22

Thomas EL, Grisham MB, Jefferson MM (1986) Preparation and characterization of chloramines. Meth Enzymol 132:569-585

Tietz N (ed) (1986) Textbook of clinical chemistry. W. B. Saunders Company, Philadelphia, PA

Timbrell JA, Seabra V, Waterfield CJ (1995) The in vivo and in vitro protective properties of taurine. Gen Pharmac 26:453-462

Winters RA, Zukowski J, Ercal N, Matthews RH, Spitz DH (1995) Analysis of glutathione, glutathione disulfide, cysteine, homocysteine, and other biological thiols by high-performance liquid chromatography following derivatization by $\mathrm{N}$-(1-pyrenyl) maleimide. Anal Biochem 227:14-21

Wright CE, Tallan HH, Lin YY (1986) Taurine: biological update. Ann Rev Biochem 55:427-453 